\title{
Exploring the Attitudes of Secondary Education Students on Environmental Education in Relation to their Perceptions on Environmental Problems: The Case of the Prefecture of Viotia
}

\author{
Filippos Zachariou ${ }^{1}$, Iro Voulgari ${ }^{2}$, Eleni Tsami ${ }^{3}$, Sotirios Bersimis ${ }^{4}$
}

\author{
${ }^{1}$ Quality Assurance Postgraduate Program, Hellenic Open University, Patras, GREECE \\ ${ }^{2}$ Laboratory Teaching Staff, Department of Early Childhood Education, National \& Kapodistrian University of Athens, Athens, GREECE \\ ${ }^{3}$ Laboratory Teaching Staff, Faculty of Finance and Statistics, University of Piraeus, Piraeus, GREECE \\ ${ }^{4}$ Associate Professor Department of Statistics and Insurance Sciences, University of Piraeus, Piraeus, GREECE \\ *Corresponding Author: etsami@yahoo.gr
}

Citation: Zachariou, F., Voulgari, I., Tsami, E., \& Bersimis, S. (2020). Exploring the Attitudes of Secondary Education Students on Environmental Education in Relation to their Perceptions on Environmental Problems: The Case of the Prefecture of Viotia. Interdisciplinary Journal of Environmental and Science Education, 16(1), e02208. https://doi.org/10.29333/ijese/6442

\section{ARTICLE INFO}

Received: 7 Mar. 2019

Revised: 7 May. 2019

Accepted: 7 May. 2019

\begin{abstract}
In this paper we explore the attitudes of secondary education students towards environmental problems and environmental education. The study took place in Viotia prefecture in Greece, a largely heterogeneous area with a high degree of industrialization and consequent environmental problems. Data were collected through a survey and the sample size was 1059 students. The main findings involve the relation of the students' perceptions on environmental education with factors such as their awareness of environmental problems, gender, family background, type of school, and place of residence. The findings also indicate that the more aware of the environmental problems the students were, the more willing they were to participate in environmental education programs. Our findings could provide relevant insights for the design of Environmental Education implementation policies.
\end{abstract}

Keywords: environmental education, environment, students' attitudes, students' views, spatial analysis, statistical analysis

\section{INTRODUCTION}

Environmental Education is closely linked to attitudes and behaviours of individuals towards the environment and relevant problems (Tilbury, 1995). In this study, we focus on two concepts: the attitudes towards the environment, and Environmental Education. Positive or negative environmental behavior seems to be linked to the people's attitudes towards the environment (see also Sarkar, 2011; Stevenson et al., 2013). We present part of an extended study on teachers' and students' attitudes towards the environment, environmental problems, and environmental education in the Viotia prefecture of Greece. In this paper, we examine the students' attitudes towards environmental problems and education, in relation to their attitudes towards the environment. We also examine other factors such as their social surroundings, and the environmental issues in their place of residence or school district.

We consider the focus on secondary education critical, since Environmental Education is still an optional course in secondary education in Greece, regardless of its major role for the development of knowledge, responsible behavior, skills, social action, and habits of students towards the environment (Hukle, 1999; Hungerford et al., 1990; Palmer, 1998), and the interdisciplinary and innovative instructional methods involved (Ajzen and Fishbein, 1980; Daskolia, 2005; Daskolia et al., 2012; Kynigos et al., 2013; Schiza, 2005; Shephard et al., 2009; Spiropoulou, 2002).

The research question is: exploring the Attitudes of Secondary Education Students on Environmental Education in relation to their Perceptions on Environmental Problems. On this basis, we will explore the following concepts.

As Environment we view "the complete range of external conditions (physical and biological) with which people interact in their life and economic activities." (Kotlyakov and Komarova, 2007). The term Environment encompasses both the Natural Environment, which involves complete ecological units that function without massive human intervention (e.g. vegetation, microorganisms, soil, rocks, atmosphere, natural phenomena) and universal natural resources such as air, water, and climate, energy, radiation, as well as the Built 
Environment, which involves the areas and components that are strongly influenced by human activity. An extensive geographical area is considered as a natural environment while a city is regarded as a built environment (Beder, 2006).

\section{RESEARCH BACKGROUND}

\section{Environmental Education in Greece}

In Greece, the idea of Environmental Education first appeared towards the end of 1976. In 1980-1981, environmental education was introduced in secondary education as an Optional Educational Innovation. Since 1990, it has been a permanent part of school curricula with the aim to raise the students' awareness on the interrelation of humans with their natural and social environment. It also deals with issues of sustainable management, environmental development and the importance of sensible use of natural resources (Daskolia, 2005; Daskolia et al., 2012; Kynigos et al., 2013; Papadopoulos, 2005; Trikaliti, 1995). The courses of environmental education and local-scale environmental projects, however, still remain mainly optional in the school curricula.

\section{Attitudes on the Environment and Environmental Education}

Our study focuses on the students' attitudes, beliefs and perceptions on the environment and Environmental Education. We address the concept of attitudes in EE as the tendencies, the predisposition of the individual to respond to particular events, individuals or organizations, objects or lessons (Hart, 2003). Attitudes are based on knowledge, they derive from past experiences -positive or negative- of the individual, they contain the element of subjectivity, and they affect the feelings and behavior. Perceptions consist of the beliefs relevant to an object or a situation. They involve a high degree of subjectivity. As Smith argues, perception is related to belief and although we do not necessarily "believe in the existence of the objects we perceive, nor that they actually have their ostensible characteristics [...] the relation between perception and belief is more than merely contingent" (Smith, 2001). Beliefs or the belief system constitute subjective knowledge and theories (Chawla \& Cushing, 2007). They are founded on personal experiences and the individual's worldview, they are subconscious, and the presence of emotion is intense. Beliefs have a cognitive character and provide a framework against which new experiences and knowledge is tested and embedded. New experiences and knowledge can, therefore, shape existing beliefs (Chawla \& Cushing, 2007; Ruffell et al., 1998). Since attitudes and beliefs can, in this context, be affected by previous experience and new information and knowledge, and they can also impact the individual's behaviour we consider the examination of the students' current attitudes and beliefs critical for the design of relevant interventions and education policies.

Environmental attitudes and behaviors of adult individual have indeed been the focus of a well established and rapidly expanding knowledge base (Buttell, 1987; Gardner \& Stern, 2002; Gifford, 2002; Schultz, 2001; Staats, 2003; Stern, 2000; Winter \& Koger, 2004; Vining \& Ebreo, 2002). It seems that adults' environmental attitudes are rooted in beliefs about anthropocentrism, limits to growth, the balance of nature, and concerns about ecological crisis (Dunlap \& van Liere, 1978; Dunlap et al., 2000; Gardner \& Stern, 2002; Evans et al., 2007). Adults with higher educational attainment, less political conservatism, more feminist beliefs, and less religious fundamentalism hold more pro-environment, "green" attitudes and values (Gardner \& Stern, 2002; Gifford, 2002; Winter \& Koger, 2004).

Previous studies on the dynamics of environmental education emphasize the role of the teachers and their attitudes (Shephard et al., 2009; Waktola, 2009; Zachariou et al., 2017). Zachariou et al. (2017) explored how the teachers' attitudes towards environmental education are influenced by local environmental problems in the place of residence or in the place of the school, as well as by their family and social surroundings and other factors. One of the most interesting conclusions of their study was that knowledge and adequate information on environmental issues create positive attitudes towards environmental education.

Generally this work shows that environmental attitudes can predict behavioural intentions; however, translation into environmental behaviors is dependent on the obstacles and difficulties associated with implementing the environmental behavior (Gardner \& Stern, 2002; Kaiser, 1998, 2004). In a meta-analysis of environmental attitudes and environmental behavior studies, the mean correlation between environmental attitudes and behaviors was .35 (Hines et al., 1987). When the available opportunities and difficulties and/or obstacles of engaging in a specified environmental behavior are incorporated into the attitude-behavior estimate, the correlation more than doubles (Corraliza \& Berenguer, 2000; Guagnano et al. 1995; Kaiser \& Gutscher, 2003).

Research by Aydin et al. (2011) and by Aydin and Cepni (2010) also links students' attitudes towards the environment to gender, class level, and school type. Aydin et al. (2011) aim was to examine the attitudes of primary students at gifted students' schools in Turkey. According to the results of this study, gifted students have positive attitudes towards environment. Another result indicated that gifted students' attitudes towards environment showed significant differences according to "gender" and "class level” variants. Aydin (2010) also studied the attitudes of university students towards environmental problems in Turkey. According to the results of this study, university students have positive attitudes towards environmental problems. In addition, the attitudes of university students towards environmental issues showed a significant difference according to gender and school type; no difference according to the grade level was observed.

Comprehension of the causes and solutions for environmental problems appears to be more difficult for children (Miller, 1975; Zachariou, 2008). Three teams of researchers have developed scales to assess children's environmental attitudes. Williams and McCrorie (1990) and Leeming and Dwyer (1995) based their item sampling domains on Maloney, Ward, and Braucht's (1975) scale of adult environmental attitudes, targeting at first through seventh graders about behavioral commitments, affective states, and awareness. Several limitations of these initial attempts to assess young children's environmental attitudes and behaviors 
are noteworthy. Maloney et al.’s scale (1975) was designed to gauge adult environmental attitudes, feelings, and awareness. On the other hand, the Leeming and Dwyer scale functioned better with older children and converged with teacher ratings on environmental interests shown among sixth graders.

Musser and colleagues (Musser \& Diamond, 1999; Musser \& Malkus, 1994) have developed an assessment tool for children that was derived from more contemporary sets of environmental issues and problems than those emphasized by Maloney et al.'s (1975) 30-year-old scale. Musser and colleagues also employed a forced-choice technique rather than 5-point Likert-type scales as used by Williams and McCrorie (1990) and Leeming and Dwyer (1995). The latter raises concerns about maintenance of attention and involvement in the instrument among children (Evans et al., 2007).

Renegotiating the perspective of view environmental problems, shifting from more anthropocentric views to situating nature at the core of discussions with the students could be one way to rise awareness of environmental problems (Bonnett, 2007).

\section{Research Objective}

Our main research question is the relation between the students' perceptions and attitudes towards EE, their beliefs and perceptions on environmental problems in their place of residence or school, and demographic characteristics such as the students' gender, level of education, and area of residence. For the collection of the data, we constructed a survey involving the perceptions, attitudes, and beliefs of the participants on five main concepts: noise pollution, air pollution, water pollution, soil pollution, environmental programs implemented at school.

\section{METHODOLOGY}

\section{Education in Viotia prefecture}

The survey took place in Viotia, one of the most highly heterogeneous prefectures in Greece. This is because this area includes a vast variety of urban centers, industrial regions and agricultural areas. It was selected as it is actually one of the most industrialized areas in Greece, with a number of environmental problems such as water contamination. It was therefore, assumed, that the environmental problems would be more apparent to our target group.

In Viotia there are several educational institutions of all educational levels. Especially for secondary education, there are 64 school units (high schools, general high schools, senior vocational high schools and vocational schools) of 7177 students in total. In most of the schools of this prefecture, students participate in activities relevant to the environment and environmental education (Zachariou, 2008).

\section{Sampling}

The target population of this study was the secondary education students in Viotia prefecture. The sampling unit was "the student" and as sampling frame we used the total number of students of the aforementioned schools. The sampling technique used is the stratified sampling with proportional allocation method (Cochran, 1977; Kiss, 1995). Strata were defined according to the urbanization level of the region with the school under research. More specifically 7177 pupils attended secondary education in the prefecture of Viotia at the time of the survey ( $\mathrm{M}=7177$ student sample points). The sizes of the strata we have formed are:

- Strata 1: M1 = 4015 students attending urban schools.

- Strata 2: M2 = 2312 students attending semicircular schools.

- Strata 3: M3 = 850 students attending rural schools.

Sampling ratio $f=n / N$ equals 0.2 (20\%). Following the implementation of the above, a total sample of 1059 pupils consisted of 449 pupils from urban areas, 324 semi-urban students and 286 pupils from rural areas. Before the main survey, a pilot survey was conducted for testing the reliability and the validity of the questionnaire. The demographics' of the participants are presented in Table 7.

\section{Research Instrument}

Our main data collection instrument was a questionnaire. The students answered the questionnaire individually during school hours. For our survey, there were questions on demographic and personal characteristics of the students (gender, age, place of residence, educational level, parents' educational level, etc.) as well as ten other groups (scales) of questions concerning the analysis of the respondents' attitudes and their awareness on environmental education and quality. In this paper, we present the results of the analysis of five out of ten groups (scales) of questions that aim at exploring attitudes and perceptions. Specifically, we examine the following scales: (i) Scale A: contains questions for exploring the students' awareness about noise problems and noise pollution in the environment, (ii) Scale B: contains questions for exploring the students' awareness about problems in the atmosphere, (iii) Scale C: contains questions for exploring the students' awareness about water pollution problems, (iv) Scale D: contains questions for exploring the students' awareness about problems in the soil, (v) Finally, in Scale E there were questions on environment-related programs that are being implemented in Secondary Education schools.

The questions of Scale E address one of the main research questions of this study (students' attitudes and perceptions on environmental education) while the other four groups of questions (Scales A, B, C and D) were used for the examination of whether and how attitudes and perceptions of students on environmental education are related with their attitudes on the causes and importance of environmental problems at their place of residence and/or school.

In each one of the questions (of the 5 scales), the respondents answered a seven-point Likert-type scale where 1 corresponded to the lowest level of agreement and 7 to the highest. In each group of questions (Scale) we applied factor analyses which produced a number of factors summarising the questions. The statistical analysis was performed using SPSS (Version 18). 
Table 1. Descriptive Statistics for the first group of questions (Group A)

\begin{tabular}{|c|c|c|c|c|c|c|c|c|c|}
\hline \multirow{2}{*}{$\begin{array}{l}\text { Question (Scale A): } \\
\text { Annoyance level due to noise produced by ... }\end{array}$} & \multicolumn{3}{|c|}{ Summary Statistics } & \multicolumn{2}{|c|}{$\begin{array}{l}\text { 95\% Confidence } \\
\text { Interval } \\
\end{array}$} & \multicolumn{4}{|c|}{$\begin{array}{c}\text { Factor Analysis Results } \\
\text { (Scale's Cronbach's alpha }=0.893) \\
\end{array}$} \\
\hline & $\mathbf{N}$ & Mean & Std. Dev. & LB & UB & $\begin{array}{c}\text { A.I } \\
(16.3 \%)\end{array}$ & $\begin{array}{c}\text { A.II } \\
(16.1 \%)\end{array}$ & $\begin{array}{c}\text { A.III } \\
(12.4 \%)\end{array}$ & $\begin{array}{l}\text { A.IV } \\
(9.5 \%)\end{array}$ \\
\hline A.1. road traffic & 1059 & 3.35 & 1.90 & 3.23 & 3.47 & .503 & & & \\
\hline A.2. air traffic & 1059 & 2.06 & 1.62 & 1.96 & 2.16 & .647 & & & \\
\hline A.3. rail traffic & 1059 & 1.89 & 1.55 & 1.79 & 1.98 & .684 & & & \\
\hline A.4. industrial sites & 1059 & 2.62 & 1.96 & 2.50 & 2.74 & .735 & & & \\
\hline A.5. military sites & 1059 & 1.82 & 1.56 & 1.72 & 1.91 & .611 & & & \\
\hline A.6. private and public sector worksites & 1059 & 3.03 & 1.90 & 2.93 & 3.16 & .675 & & & \\
\hline A.7. agricultural activities & 1059 & 2.86 & 2.04 & 2.73 & 2.98 & & .522 & & \\
\hline A.8. schools & 1059 & 2.61 & 2.00 & 2.49 & 2.73 & & & .567 & \\
\hline A.9. entertainment centers & 1059 & 2.76 & 1.98 & 2.64 & 2.89 & & & .699 & \\
\hline A.10. recreational centers & 1059 & 2.18 & 1.71 & 2.07 & 2.28 & & & .698 & \\
\hline A.11. usage of explosive materials & 1059 & 2.24 & 1.94 & 2.13 & 2.36 & .528 & & & \\
\hline A.12. animals & 1059 & 2.67 & 1.84 & 2.56 & 2.79 & & .638 & & \\
\hline A.13. street markets & 1059 & 2.35 & 1.59 & 2.26 & 2.45 & & .517 & & \\
\hline A.14 neighbors & 1059 & 3.16 & 2.04 & 3.04 & 3.28 & & .725 & & \\
\hline A.15. peddlers & 1059 & 2.91 & 1.83 & 2.80 & 3.01 & & .569 & & \\
\hline A.16. random activities & 1059 & 2.55 & 1.75 & 2.45 & 2.65 & & .501 & & \\
\hline A.17. household appliances & 1059 & 2.85 & 1.91 & 2.73 & 2.96 & & .640 & & \\
\hline A.18. chats/speeches & 1059 & 2.67 & 1.90 & 2.55 & 2.79 & & .595 & & \\
\hline A.19. security vehicles & 1059 & 2.40 & 1.81 & 2.29 & 2.51 & & & & .722 \\
\hline A.20. ambulances & 1059 & 2.10 & 1.63 & 2.00 & 2.20 & & & & .716 \\
\hline
\end{tabular}

Table 2. Descriptive Statistics for the first group of questions (Group B)

\begin{tabular}{|c|c|c|c|c|c|c|c|c|c|}
\hline \multirow{2}{*}{$\begin{array}{l}\text { Question (Scale B): } \\
\text { Atmospheric pollution due to ... }\end{array}$} & \multicolumn{3}{|c|}{ Summary Statistics } & \multicolumn{2}{|c|}{$\begin{array}{l}\text { 95\% Confidence } \\
\text { Interval } \\
\end{array}$} & \multicolumn{4}{|c|}{$\begin{array}{c}\text { Factor Analysis Results } \\
\text { (Scale's Cronbach's alpha }=0.899 \text { ) }\end{array}$} \\
\hline & $\mathbf{N}$ & Mean & Std. Dev. & LB & UB & $\begin{array}{c}\text { B.I } \\
(\mathbf{1 7 . 7 \% )}\end{array}$ & $\begin{array}{c}\text { B.II } \\
(14.5 \%)\end{array}$ & $\begin{array}{c}\text { B.III } \\
(14.3 \%)\end{array}$ & $\begin{array}{c}\text { B.IV } \\
(11.9 \%)\end{array}$ \\
\hline B.1. road traffic (automobiles, etc) & 1059 & 4.78 & 2.03 & 4.64 & 4.90 & & & .494 & \\
\hline B.2. air traffic (airplanes...) & 1059 & 3.28 & 1.96 & 3.16 & 3.40 & & & .818 & \\
\hline B.3. railroad traffic & 1059 & 3.02 & 1.80 & 2.90 & 3.13 & & & .802 & \\
\hline B.4 industrial sites & 1059 & 4.78 & 2.22 & 4.64 & 4.92 & & & .618 & \\
\hline B.5. private and public sector worksites & 1059 & 3.94 & 1.92 & 3.82 & 4.06 & & & .567 & \\
\hline B.6. garbage disposal & 1059 & 4.94 & 1.97 & 4.82 & 5.05 & .441 & & & \\
\hline B.7. heating & 1059 & 3.98 & 1.83 & 3.86 & 4.08 & & & & .480 \\
\hline B.8. telecommunications & 1059 & 3.37 & 1.89 & 3.25 & 3.49 & & & & .673 \\
\hline B.9. spray usage & 1059 & 4.12 & 2.07 & 3.98 & 4.23 & & .752 & & \\
\hline B.10. insecticides / pesticides / fertilizers & 1059 & 4.73 & 2.02 & 4.60 & 4.86 & & .734 & & \\
\hline B.11. energy production & 1059 & 3.90 & 1.99 & 3.77 & 4.02 & & .645 & & \\
\hline B.12. agricultural areas combustion & 1059 & 4.15 & 1.89 & 4.03 & 4.26 & & .498 & & \\
\hline B.13. fires & 1059 & 4.81 & 2.05 & 4.67 & 4.93 & .585 & & & \\
\hline B.14. smoking & 1059 & 4.64 & 2.09 & 4.50 & 4.76 & .460 & & & \\
\hline B.15. breathing & 1059 & 2.90 & 2.13 & 2.77 & 3.04 & & & & .834 \\
\hline B.16. dead organisms & 1059 & 3.45 & 2.01 & 3.32 & 3.57 & & & & .600 \\
\hline B.17. climate change & 1059 & 4.18 & 1.97 & 4.05 & 4.31 & .627 & & & \\
\hline B.18. soil pollution & 1059 & 4.93 & 1.98 & 4.81 & 5.06 & .777 & & & \\
\hline B.19. water pollution & 1059 & 5.04 & 2.10 & 4.91 & 5.16 & .751 & & & \\
\hline B.20. random incidents & 1059 & 3.91 & 1.99 & 3.78 & 4.03 & .568 & & & \\
\hline
\end{tabular}

\section{Statistical Analysis Techniques}

For the analysis, methods from Descriptive and Inferential Statistics were used (Field, 2013; Sachlas \& Bersimis, 2016; Tsantas et al., 1999) in combination with multivariate techniques such as "Factor Analysis" (Bartholomew et al., 2008) and "Reliability Analysis". Factor analysis can be applied to large quantities of correlated data in order to describe variability among observed, correlated variables and to transforming them into a lower number of unobserved, uncorrelated variables, referred to as factors. Reliability analysis is used in order to measure the internal consistency of each questionnaire (in this study we use Cronbach's alpha coefficient).

\section{DESCRIPTIVE ANALYSIS}

\section{Presentation of the Scales}

As previously discussed, Scale A consists of questions on the students' level of awareness on the existence of noise problems / noise pollution in the environment. The analysis of data showed that students do not seem to mind about the various sources of noise (all responses were lower than the mid-point on the Likert scale (i.e., 3.5) - see Table 1). Scale B consists of questions on the students' level of awareness of problems in the atmosphere. The results are presented in Table 2. The students' degree of awareness of the current situation was around the mean value (i.e. 4.0) for most of the examined parameters (Table 2), with the exception of the contribution of water pollution. This may be attributed to the 
Table 3. Descriptive Statistics for the first group of questions (Group C)

\begin{tabular}{|c|c|c|c|c|c|c|c|c|c|}
\hline \multirow{2}{*}{$\begin{array}{l}\text { Question (Scale C): } \\
\text { Water pollution due to ... }\end{array}$} & \multicolumn{3}{|c|}{ Summary Statistics } & \multicolumn{2}{|c|}{$\begin{array}{l}\text { 95\% Confidence } \\
\text { Interval } \\
\end{array}$} & \multicolumn{4}{|c|}{$\begin{array}{c}\text { Factor Analysis Results } \\
(\text { Scale's Cronbach's alpha }=0.915) \\
\end{array}$} \\
\hline & $\mathbf{N}$ & Mean & Std. Dev. & LB & UB & $\begin{array}{c}\text { C.I } \\
(21.0 \%) \\
\end{array}$ & $\begin{array}{c}\text { C.II } \\
(17.7 \%)\end{array}$ & $\begin{array}{c}\text { C.III } \\
(14.1 \%)\end{array}$ & $\begin{array}{l}\text { C.IV } \\
(8.8 \%)\end{array}$ \\
\hline C.2. garbage disposal & 1059 & 4.91 & 1.92 & 4.80 & 5.03 & .709 & & & \\
\hline C.3. industrial waste & 1059 & 5.18 & 2.09 & 5.04 & 5.30 & .744 & & & \\
\hline C.4. private and public sector worksites & 1059 & 4.23 & 1.85 & 4.11 & 4.34 & .706 & & & \\
\hline C.5. animal breeding waste & 1059 & 4.10 & 1.90 & 3.98 & 4.21 & .660 & & & \\
\hline C.6. aquiculture & 1059 & 3.86 & 1.94 & 3.74 & 3.97 & .585 & & & \\
\hline C.7. noise & 1059 & 3.24 & 2.09 & 3.12 & 3.37 & & & .776 & \\
\hline C.8. radiation & 1059 & 3.59 & 2.02 & 3.46 & 3.72 & & & .712 & \\
\hline C.9. urban pluvial flooding & 1059 & 3.94 & 1.92 & 3.82 & 4.05 & .562 & & & \\
\hline C.10. oil-related products & 1059 & 4.71 & 2.18 & 4.57 & 4.85 & .648 & & & \\
\hline C.11. energy production (hydroelectric stations) & 1059 & 3.81 & 2.98 & 3.64 & 3.98 & .400 & & & \\
\hline C.12. water usage for washing & 1059 & 4.07 & 1.92 & 3.96 & 4.19 & & & & .810 \\
\hline C.13. water usage as refrigerating means & 1059 & 3.79 & 1.90 & 3.68 & 3.91 & & & & .753 \\
\hline C.15. fertilizers usage & 1059 & 5.10 & 1.95 & 4.97 & 5.22 & & .720 & & \\
\hline C.16. dead organisms & 1059 & 4.07 & 1.96 & 3.95 & 4.20 & & .577 & & \\
\hline C.17. climate change & 1059 & 4.24 & 1.96 & 4.11 & 4.36 & & .649 & & \\
\hline C.18. soil pollution & 1059 & 4.87 & 2.01 & 4.74 & 4.99 & & .764 & & \\
\hline C.19. air pollution & 1059 & 4.52 & 2.03 & 4.40 & 4.65 & & .654 & & \\
\hline C.20. random incidents & 1059 & 3.66 & 2.01 & 3.54 & 3.78 & & & .602 & \\
\hline
\end{tabular}

Table 4. Descriptive Statistics for the first group of questions (Group D)

\begin{tabular}{|c|c|c|c|c|c|c|c|c|c|}
\hline \multirow{2}{*}{$\begin{array}{l}\text { Question (Scale D): } \\
\text { Soil pollution due to ... }\end{array}$} & \multicolumn{3}{|c|}{ Summary Statistics } & \multicolumn{2}{|c|}{$\begin{array}{l}\text { 95\% Confidence } \\
\text { Interval }\end{array}$} & \multicolumn{4}{|c|}{$\begin{array}{c}\text { Factor Analysis Results } \\
\text { (Scale's Cronbach's alpha }=\mathbf{0 . 9 1 1 )}\end{array}$} \\
\hline & $\mathbf{N}$ & Mean & Std. Dev. & LB & UB & $\begin{array}{c}\text { D.I } \\
(16.7 \%)\end{array}$ & $\begin{array}{c}\text { D.II } \\
(16.6 \%)\end{array}$ & $\begin{array}{c}\text { D.III } \\
(15.7 \%)\end{array}$ & $\begin{array}{l}\text { D.IV } \\
(9.8 \%)\end{array}$ \\
\hline D.2. garbage disposal & 1059 & 4.87 & 1.93 & 4.76 & 4.99 & .835 & & & \\
\hline D.3. industrial sites & 1059 & 4.84 & 2.10 & 4.70 & 4.96 & .750 & & & \\
\hline D.4. road openings & 1059 & 4.08 & 1.72 & 3.97 & 4.17 & & .687 & & \\
\hline D.5. railway opening & 1059 & 3.59 & 1.80 & 3.48 & 3.70 & & .766 & & \\
\hline D.6. underground network supply & 1059 & 3.89 & 1.85 & 3.77 & 4.00 & & .745 & & \\
\hline D.7. excavation & 1059 & 4.00 & 1.87 & 3.88 & 4.10 & & .565 & & \\
\hline D.8. construction building & 1059 & 4.01 & 1.78 & 3.90 & 4.12 & & .594 & & \\
\hline D.9. touristic activities & 1059 & 3.79 & 1.88 & 3.67 & 3.89 & & .562 & & \\
\hline D.10. oil-related products & 1059 & 4.65 & 2.11 & 4.53 & 4.77 & .623 & & & \\
\hline D.11. timber-cutting & 1059 & 4.08 & 1.94 & 3.96 & 4.21 & .482 & & & \\
\hline D.12. pasture & 1059 & 3.49 & 1.91 & 3.37 & 3.60 & & & & .782 \\
\hline D.13. agricultural activities & 1059 & 4.04 & 1.91 & 3.92 & 4.16 & & & & .772 \\
\hline D.15. combustion leftovers & 1059 & 4.55 & 2.00 & 4.44 & 4.67 & & & .551 & \\
\hline D.16. dead organisms & 1059 & 3.83 & 1.97 & 3.71 & 3.94 & & & .599 & \\
\hline D.17. climate change & 1059 & 4.15 & 1.95 & 4.04 & 4.26 & & & .684 & \\
\hline D.18. water pollution & 1059 & 4.80 & 1.98 & 4.68 & 4.91 & & & .717 & \\
\hline D.19. air pollution & 1059 & 4.58 & 2.00 & 4.46 & 4.71 & & & .746 & \\
\hline D.20. random incidents & 1059 & 4.00 & 2.03 & 3.87 & 4.12 & & & .548 & \\
\hline
\end{tabular}

intense problem of water pollution in that region over the past years. The results for Scale $\mathrm{C}$, consisting of questions on the students' level of awareness of problems in the water, are presented in Table 3. High mean score were observed for the industrial waste (mean=5.18, $\mathrm{SD}=2.09)$, pollution from pesticides (mean=5.16, $\mathrm{SD}=1.93$ ) and the pollution from fertilizers (mean=5.10, $\mathrm{SD}=1.95)$. The relatively high mean score of these parameters is possibly due to the intense problem of water pollution in the area, an issue that had been highly publicized in the media. Descriptive results of Scale D are presented in Table 4 . The respondents had an average awareness of the problems in the soil in their area. This is normal since pollution in the soil is a slow process that is not easily noticed especially in urban areas (Zachariou, 2008). We obtained the factors using Principal Component Analysis (PCA) with varimax rotation as well as KMO measures. Based on data from the Scale E items, students seem to consider the implementation of Environmental Education in schools to be important and believe that these programs should expand to every aspect of society (see Table 1). At the same time, they believe that it should be obligatory for students and professors to participate in such environment-related programs implemented in schools and that these environment-related programs should be included in the school calendar in the form of obligatory classes.

\section{EXPLORATORY ANALYSIS}

\section{Factor Analysis}

We conducted an exploratory factor analysis for an indepth analysis of the data. The factor analysis method is based on a transformation that expresses the initial (real) parameters 
as linear combinations of some new (unobservable) parameters (factors). The linear combinations that are created essentially interpret the structure of the data. The new variables (factors) are independent (in most of the cases). The most prominent factors represent the largest part of the information contained in the data and a true-to-life interpretation can be attributed to them. As already mentioned the PCA method was used for obtaining the factors. The factor analysis was applied in each scale independently. Thus, after extracting the significant factors, the correlation among factors of different scales was explored.

\section{Scale A}

The application of factor analysis on the answers of Scale A resulted in the following 4 factors:

Questions A.1, A.2, A.3, A.4, A.5, A.6, and A.11 can be grouped under the factor Annoyance Level Due to Noise Produced by Everyday Life Actions (Factor A.II). In this factor, the answer to Question A.4 seems to be the most influential. This comes as no surprise since Viotia is a heavily industrialized area.

Questions A.7, A.12, A.13, A.14, A.15, A.16, A.17 and A.18 (see Table 1) can be grouped under the factor labeled as Annoyance Level Due to Noise Produced by Constructions and Traffic (Factor A.I). It should be noted that the variable with the highest correlation with this factor is the disturbance in the neighborhood, which can be attributed to the fact that the students may be more annoyed by surrounding sources of noise during their home-study hours at home.

Questions A8, A.9 and A.10 (Table 1) are related to the factor Annoyance Level Due to Noise Produced by Citizens (Factor A.III). It seems that the night clubs are, as expected, the most important factor since the noise levels are significantly higher in places where people under 20 years of age, such as students, usually spend their time.

Questions A.19 and A.20 (Table 1) are related to the factor Annoyance Level Due to Noise Produced by Emergency Vehicles (Factor A.IV). The two parameters grouped under this factor have no standard frequency of appearance and usually appear as random facts.

The Cronbach's alpha reliability coefficient is equal to 0.893 for this scale. This is a very high value which confirms that the analysis is reliable.

\section{Scale B}

For the Scale B items, factor analysis also produced 4 factors:

The most significant factor is the Atmospheric Pollution Due to Other Types of Pollution (Factor B.I) which groups questions B.1, B.4, B.6, B.13, B.14 B.17, B.18, B.19 and B.20 (Table 2). In this group, the most important sources of pollution are perceived to be those which release large quantities of pollutant agents in the atmosphere, such as fires, combustions and sprayings. The interrelation between climate change and soil and water pollution was a noteworthy finding at this point.

The second more significant factor is Atmospheric Pollution Due to Industrial and Non Industrial Production (Factor B.II) which groups questions B.9, B10, B.11 and B.12.
We further have the factor Atmospheric Pollution Due to Sources Related to Traffic (Factor B.III) which groups questions B.1, B.2, B.3, B4. B5. This grouping with relatively high loadings of all the parameters may be linked, concerning the students' perceptions, to the traffic generated in Viotia prefecture by the main railway line axis connecting Athens with Central and Northern Greece, which runs across Viotia and through residential areas, and the nearby airport sites.

Finally, we have the factor Atmospheric Pollution Due to Human Way of Living (Factor B.IV) which groups questions B.7, B.9, B.15 and B.16 (Table 2).

Cronbach's alpha reliability coefficient is equal to 0.899 for this scale, which is again a very high value.

\section{Scale C}

Scale C, presented in Table 3, aimed at the exploration of the students' awareness on water pollution and its causes. Factor analysis produced five factors: The most significant factor is the Water Pollution Due to Human Way of Living (Factor C.I) which groups questions C.1, C.2, C.3, C.4, C.5, C.6, C.9, C.10, and C.11 (Table 3). The items grouped in this factor are the most mentioned ones as causes of the intense pollution problems in the aquifer of the area, and during the time of the survey, it constituted a major problem for the local community.

The second more significant factor is Water Pollution Due to Other Types of Pollution (Factor C.II) which groups questions C.14, C.15, C.16, C.17, C.18 and C.19 since all of them are relevant to the BioGeoChemical water cycle. The factoring in of parameters such as pesticides and fertilizers is quite noticeable. This may be attributed to the fact that the prefecture has a highly intensive agricultural activity and these specific parameters are mostly the reasons for pollution of water in the area, which is, as mentioned earlier, the most prominent problem the prefecture was coping with during the time of the survey.

The third more significant factor is Water Pollution Due to Extreme Factors Related to Production (Factor C.III) group questions C.7, C.8 and C.20 (Table 3). It was highly noticeable that while the initial parameters seemed irrelevant, it is the students' view that these parameters converge towards the degradation of water quality.

The fourth more significant factor is Water Pollution Due to Its Everyday Use (Factor C.IV) which groups questions C.12 and C.13 (Table 3) where the highest loading was that of the item concerning water for washing or as a refrigerating agent.

The Cronbach's alpha reliability coefficient is equal to 0.915 for this scale (very high value).

\section{Scale D}

Questions of Scale D explore the students' awareness on the existence of pollution problems in the soil (Table 4). The analysis produced four factors:

The first factor is Soil Pollution Due to Human Way of Living (Factor D.I) and it groups the questions D.1, D.2, D.3, D.10 and D.11. In this factor, the participation of the item on garbage disposal was significant; this was not surprising considering the fact that garbage disposal in the ground can be 
Table 5. Descriptive Statistics for the first group of questions (Group E)

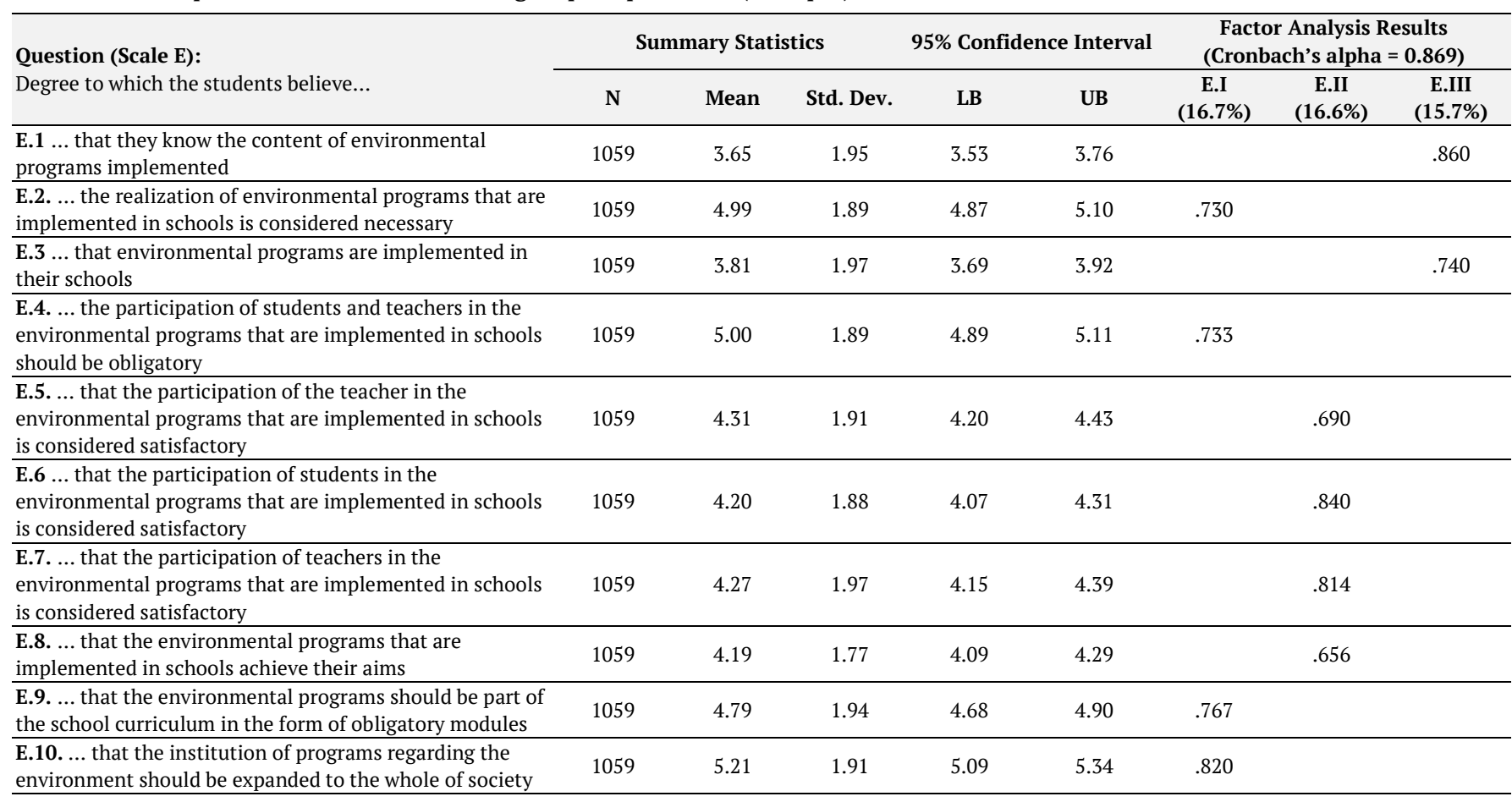

easily perceived by the students as it is noticeable in their immediate environment.

The second factor is Soil Pollution Due to Other Types of Pollution (Factor D.III) which groups questions D.4, D.5, D.6, D.7, D.8, and D.9 (Table 4). The common trait of all these parameters is that their effects are immediately visible since they distort the morphology of the ground.

The factor Soil Pollution Due to Construction and Production (Factor D.II) groups questions D.15, D.16, D.17, D.18, D.19 and D.20 (Table 4), which overall is similar to factor C.II, but in this case in reference to soil pollution.

The fourth more significant factor is Soil Pollution Due to Agricultural and Livestock Production (Factor D.IV) which groups questions D.14, D.15, and D.16 (Table 4). The common characteristic of these items is, again, that the phenomena described are immediately visible. It is worth noticing that combustion is the most common way of clearing the agricultural spaces of the prefecture, and also the bad conditions of the road network is the cause of death for many animals hit by passing vehicles and are left to decompose without proper disposal.

The Cronbach's alpha reliability coefficient is equal to 0.911 for this scale (very high value).

\section{Scale $E$}

Scale E explores the students' views and attitudes on environmental education programs implemented in secondary education. Factor analysis produced three factors:

The first factor was the Need for implementation of $\boldsymbol{E E}$ (Factor E.I) and groups the questions E.2, E.4, E.9 and E.10 (Table 5). The analysis showed that the need for increased implementation of environmental education programs throughout the community is rated very highly; students thought it is necessary to raise awareness of the community in order to have the best possible results for the protection of the environment. In addition, the students rated the need to incorporate environmental programs in the obligatory school curriculum very highly.

The second factor is Satisfaction level from Participation and Goal achievement (Factor E.II) which groups questions E.5, E.6, E.7 and E.8 (Table 5). We discovered that the implementation of EE programs, the participation of the respondents themselves and goal achievement are of low importance, whereas participation of students and educators seems high. This can be explained by the fact that the professors participate in these programs with an additional motive to supplement their working hours and the students aim at an alternative approach to knowledge and the activities that usually accompany these programs, such as educational field visits.

Finally, the factor Level of knowledge and Application of $\boldsymbol{E} \boldsymbol{E}$ (Factor E.III) groups questions E.1 and E.3 (Table 5). The results indicated that knowledge coming from peers promotes students' participation.

The Cronbach's alpha reliability coefficient is equal to 0.869 for this scale (very high value).

Exploring Correlation among Factors Relevant to the Students' Attitudes towards Environmental Education (Scale E) and the Other Scales (A-D)

We will examine correlations using Spearman 'R. The Need for implementation of $E E$ (E.I) factor is positively related to D.I: Soil Pollution Due to Human Way of Living (R=0.362, pvalue<0,001), C.II: Water Pollution Due to Other Types of Pollution ( $\mathrm{R}=0.278$, $\mathrm{p}$-value $<0,001)$, C.I: Water Pollution Due to Human Way of Living $(\mathrm{R}=0.278$, p-value $<0,001)$, B.II: Atmospheric Pollution Due to Industrial and Non Industrial Production ( $\mathrm{R}=0.192$, $\mathrm{p}$-value $<0,001$ ), B.I: Atmospheric Pollution Due to Other Types of Pollution $(\mathrm{R}=0.192$, $\mathrm{p}$-value $<0,001)$. In all the aforementioned cases, it seems that the highest the degree 
Table 6. Correlation among scale E and the other scales (A-D)

\begin{tabular}{|c|c|c|c|c|c|c|c|c|c|c|c|c|c|c|c|c|}
\hline & A.I & A.II & A.III & A.IV & B.I & B.II & B.III & B.IV & C.I & C.II & C.III & C.IV & D.I & D.II & D.III & D.IV \\
\hline E.I & n.s.* & n.s. & n.s. & n.s. & 0.192 & 0.192 & n.s. & n.s. & 0.278 & 0.278 & n.s. & n.s. & 0.362 & n.s. & n.s. & n.s. \\
\hline E.II & n.s. & 0.112 & n.s. & n.s. & 0.105 & n.s. & n.s. & 0.170 & n.s. & n.s. & 0.170 & n.s. & n.s. & 0.200 & n.s. & n.s. \\
\hline E.III & 0.115 & n.s. & n.s. & n.s. & 0.110 & n.s. & n.s. & n.s. & 0.163 & n.s. & n.s. & n.s. & 0.175 & n.s. & n.s. & n.s. \\
\hline
\end{tabular}

* not significant

of perceived environmental problems the more necessary the implementation and increase of programs that raise the citizens' awareness towards the environmental problems is perceived to be.

The Satisfaction level from Participation and Goal achievement (E.II) factor is positively related to the factors D.II: Soil Pollution Due to Construction and Production $(\mathrm{R}=0.200$, $\mathrm{p}$ value<0,001), B.IV: Atmospheric Pollution Due to Human Way of Living ( $\mathrm{R}=0.170, \mathrm{p}$-value<0,001), C.III: Water Pollution Due to Extreme Factors Related to Production $(\mathrm{R}=0.170$, $\mathrm{p}$ value<0,001), A.II: Annoyance Level Due to Noise Produced by Everyday Life Actions $(\mathrm{R}=0.112$, $\mathrm{p}$-value $<0,001)$, B.I: Atmospheric Pollution Due to Other Types of Pollution $(\mathrm{R}=0.105$, $\mathrm{p}$-value $<0,001)$. The positive relation of these factors can probably be attributed to the intensity of the situation experienced (i.e. acute environmental problems) and the awareness and willingness to actively participate in actions for the improvement of the surrounding environment.

The Level of knowledge and Application of EE (E.III) factor is positively related to the factors D.I: Soil Pollution Due to Human Way of Living $(\mathrm{R}=0.175$, $\mathrm{p}$-value $<0,001)$ and C.I: Water Pollution Due to Human Way of Living $(\mathrm{R}=0.163$, p-value $<0,001)$, A.I: Annoyance Level Due to Noise Produced by Constructions and Traffic ( $\mathrm{R}=0.115$, $\mathrm{p}$-value $<0,001)$, and B.I: Atmospheric Pollution Due to Other Types of Pollution $(\mathrm{R}=0.110$, $\mathrm{p}$-value $<0,001)$. The positive relationship is probably due to the fact that the content of most programs of environmental education implemented in schools are relevant to issues from the students' everyday life and current events, without though focusing and specializing on a specific issue (see Table 6).

\section{Relationship of Demographic Characteristics with} Students' Attitudes towards Environmental Education

\section{Relationship of the demographic characteristics with Scale $E$}

Our analysis using t-test indicated that the Need for implementation of $E E$ (E.I) factor is related to the respondents' gender ( $p$-value<1\%o). More specifically, women rated the need for implementation higher than men did (Mean for women $=0.217$, Mean for men $=-0.242$ ). This was in accordance with findings by Zachariou (2008) who observed similar differences between girls and boys in his sample of students.

Additionally the Need for implementation of EE (E.I) factor is related with the students' educational level ( $p$-value=0.002). More specifically, a positive relation was discovered among high school students (Mean=0.081) and the students in vocational schools (Mean $=0.127$ ) in contrast to general senior high school students (Mean $=-0.006$ ) and those of Vocational Senior High Schools (Mean=-0.016). For the analysis the ANOVA test was used.

This positive relation found for high school students, may be attributed to the fact that at this age the students, depending on their sensitivity towards the environment, seek alternative methods of learning about it. The positive relation of the implementation with the Vocational Schools level of education could be attributed to the fact that in these schools the admitted students have consciously decided to enroll, they are of ages often higher than the average for students of secondary level, so they are usually more self-conscious concerning their choice. The negative relation for the General High Schools may be attributed to the fact that the majority of students who chose to attend a General High School have their admittance in tertiary education as their main goal; they therefore focus on the compulsory core of classes and attend environmental education classesonly following their teachers' encouragement. Finally, the negative relation for the Vocational Senior High Schools could be a result of the absence of such programs at this level of education.

Moreover, the Satisfaction level from Participation and Goal achievement (E.II) factor is found to be relevant only with the mother's level of education ( $p$-value=0.023). More specifically, there was a positive relation when the mother was a Senior High School graduate (Mean=0.082, ) and a negative when the mother was a primary school graduate (Mean=-0.018), High School Graduate and University graduate (Mean=-0.169). Again the ANOVA method was used. It is worth mentioning at this point that the highest the level of education of the family, the highest the negative relation with the satisfaction from the EE programs. This could imply that the outcome and participation in such programs does not satisfy the expectations of the students who come from families of a higher educational level, at least from the side of the mother.

The Level of knowledge and Application of EE factor (E.III) was found to be related to the gender of respondents ( $p$ value $=0.003$ ). More specifically, women had a positive view (Mean=0.087) and men had a negative one (Mean=-0.097). This seems consisted with findings from previous studies indicating that girls show a higher level of sensitivity towards issues of environmental quality (Zachariou, 2008). The t-test was performed.

Moreover, the Level of knowledge and Application of EE factor (E.III) was found to be related to the students' level of education ( $t$-test $\mathrm{p}$-value $<1 \%$ o). More specifically, a positive relation was discovered among High School students (Mean=0.095,) and the students of General Senior High Schools (Mean=0.027). The positive relation of this factor with High School and General Senior High School students and the negative with students of other educational levels can be attributed to the fact that programs of EE take place more frequently in the first two levels while they are entirely absent from the other levels.

\section{The relation of the residence area with the factors}

The place of residence of the respondents is found to be significantly related to the factors Need for implementation of EE (E.I) and Level of knowledge and Application of EE (E.III). The 


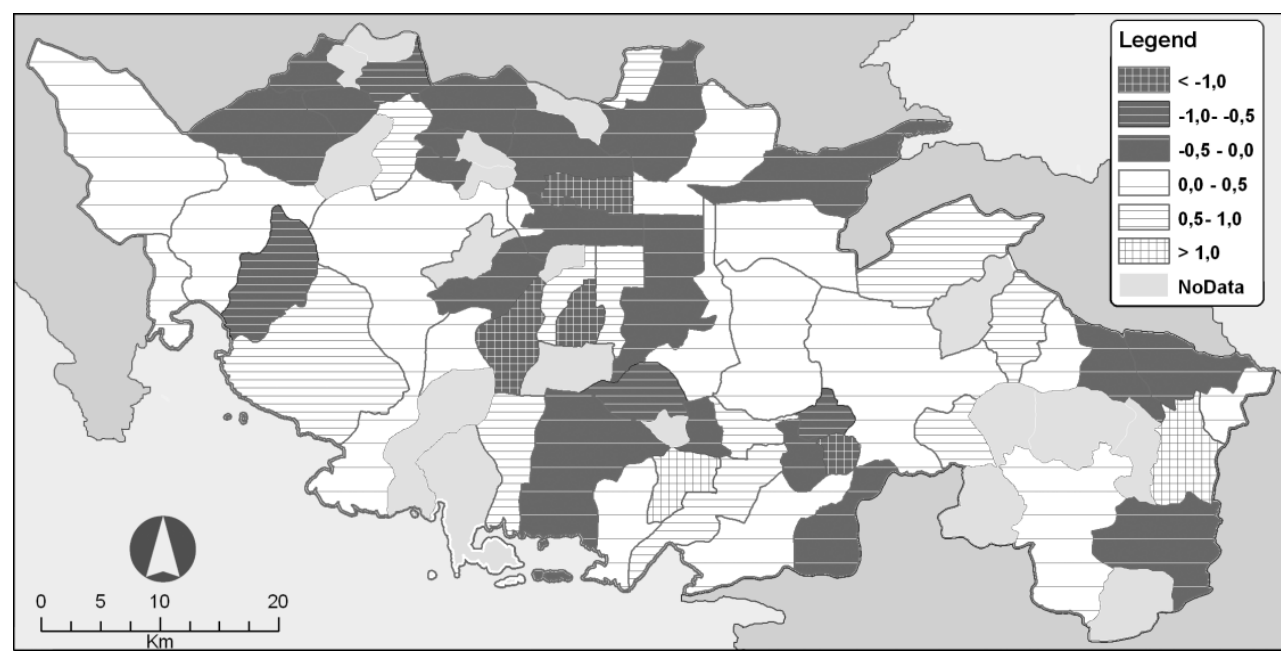

(a)

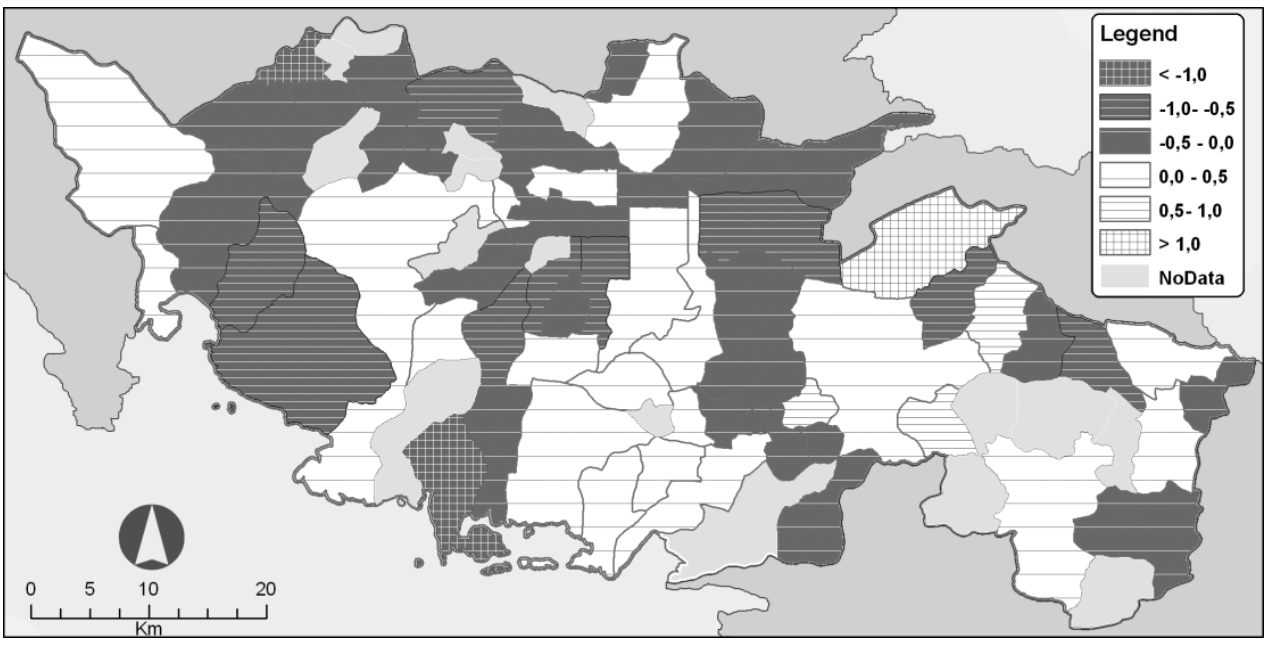

(b)

Figure 1. a) Geographic allocation according to values of the Need for implementation of EE factor in Viotia; b) Geographic allocation according to the values of the Level of knowledge and Application of EE factor in Viotia.

results of this analysis are presented in maps to have a clearer territorial mapping at the prefecture's level. For the creation of the maps, we applied the following scaling of the values of factors: (a) very negative (<-1), (b) negative $([-1,-0,5))$, (c) a little negative $([-0,5,0))$, (d) a little positive $((0,0,5])$, (e) positive $((0,5,1])$, (f) very positive $(>1)$. It should be noted that the parts of the maps with the «No Data» indication are mountainous or rural areas that are not inhabited or are scarcely inhabited. In the right side of the maps, there is also the industrial zone of Oinofyta and although there are schools and educators there and the area copes with intense environmental challenges, school of the area refused to participate in this survey.

Figure 1a shows the results of the place of residence in relation to the factor Need for implementation of EE (E.I) We observe a greater need for implementation and increase in application (values higher than mean - light colored parts of the map) in the areas around the two urban centers of the prefecture (Thebes and Livadia) as well as in the eastern part of the prefecture where industrial zones are concentrated therefore there is a significant deterioration of the natural surroundings, and problems such as water pollution because of hexavalent chromium (parts of the map with values $>1$ ). In the rest of the areas (dark-coloued parts), it seems to be a negative relationship especially because of the fact that these are mountainous or rural areas, where the environment has not been significantly deteriorated. It is worth mentioning that although there are plenty of values lower than the mean $(-0.5$ $-0.0)$, they are very close to the values of the areas a little higher than the mean $(0.0-0.5)$ and all of these areas overshadow the rest as a whole. This may be attributed to the fact that in most mountainous and rural areas, there are no schools or other provision for services. As a result, inhabitants are forced to move on an everyday basis to more urbanized areas, where they may become aware of the environmental problems.

The results of the place of residence in relation to the Level of knowledge and Application of EE factor (E.III) are mapped in Figure $\mathbf{1 b}$.

In Figure $1 \mathbf{b}$ we can see values higher than the mean in the areas (light-colored on the map) where every new intervention (e.g. the installation of a satellite dish for mobile telephony) is immediately noticed, and in areas with intense industrial development where people experience the consequences, such as the industrial zones of the prefecture. The results are consistent with our findings on the relationship of the place of 


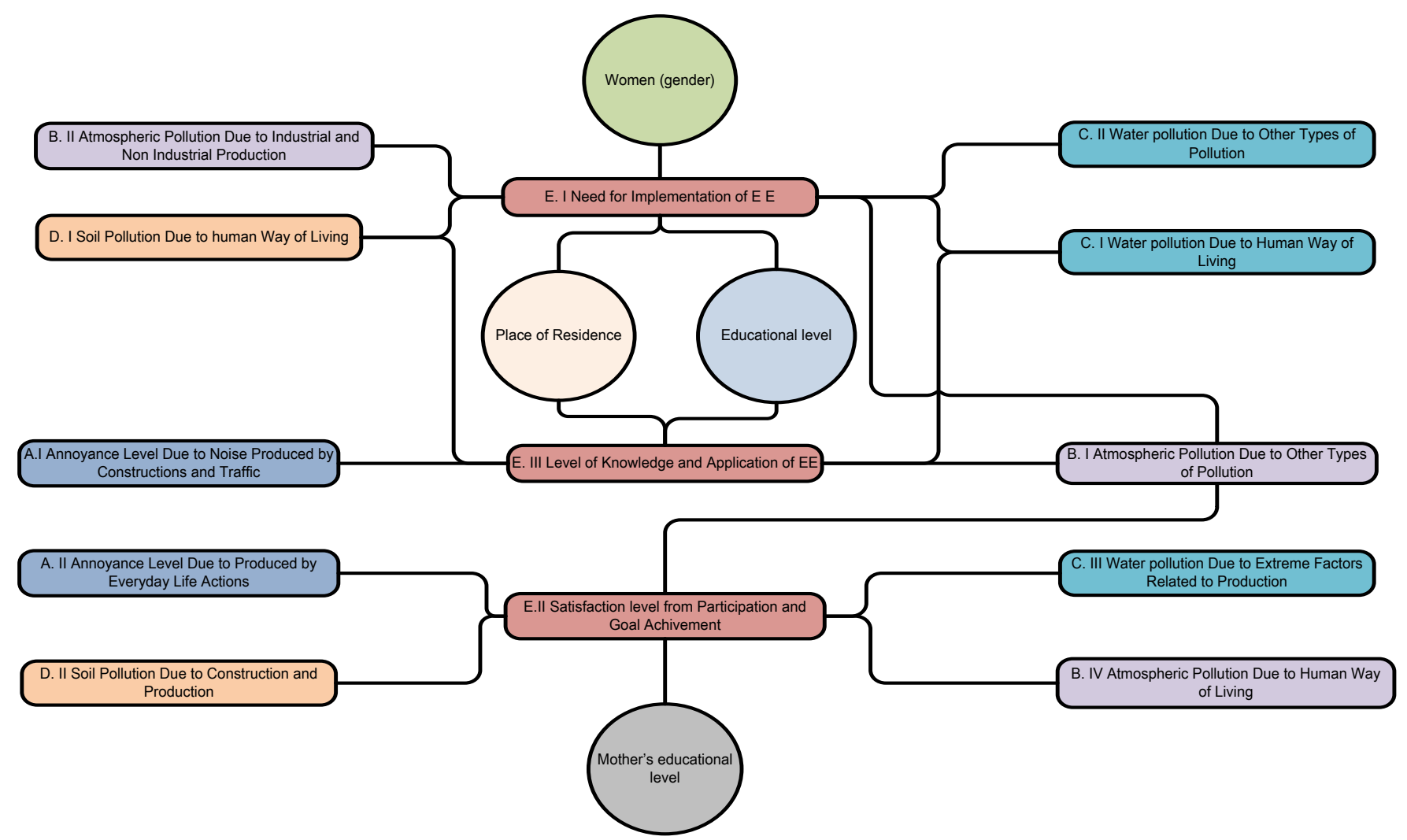

Figure 2. The framework of attitudes relations that was identifyied

residence in the previous factor. It should be mentioned that in the areas where the value of the indicator is higher and close to the mean (0.0-0.5), there is, in general, educational personnel that implements programs of environmental education on a permanent basis and in this way this personnel may affect students and shape their attitudes towards the environment.

\section{CONCLUSIONS}

Our main research objective was the exploration of the relationship of the students' perceptions and attitudes towards environmental education with their beliefs and perceptions on environmental problems in their place of residence or school. Our findings indicated that (Figure 2): The secondary education students in Viotia prefecture indicated their beliefs concerning the environmental problems. The students could attribute the problems to certain factors (atmosphere, water, etc) and evaluated them according to their perceived importance. Their belief was that the water issue as the most important problem, without downgrading the significance of the other factors. For every factor, they perceived and evaluated the causes and assessed their significance. They also recognized the interrelation of environmental problems such as air, water and soil pollution (Zachariou, 2008). The junior and senior secondary students were more concerned about their natural environments to which they showed strong positive associations (Kwan \& Miles, 1998).

Concerning their beliefs and attitudes towards the environment, we found that the highest their level of awareness of environmental problems, the more necessary it was for them to implement and increase of environment awareness programs. Also, the highest their level of awareness of environmental problems, the highest their willingness to effectively participate in programs of an environmental orientation. As it emerged from this study, beliefs and peceptions of environmental problems are relevant to the everyday life of the students at their place of residence. Broom (2017) illustrated connections between childhood experiences in nature and later views of, and actions towards, the environment.

We have to stress the fact that during the time this survey was conducted, there was a critical problem of water pollution (underground and surface) with hexavalent chromium on the eastern Viotia region, highly publicized by the media. Despite the fact that a solution has been given to the problem concerning household supply of water, the effects on the agricultural commodities of the area and the long-term consequences on human health were still to be explored. It should also be added that the Viotia prefecture is the most industrialized prefecture of the country, following Attica and Thessaloniki.

There were, also, gender and educational background related differences on the views and attitudes of students towards environmental education: the girls and students of general education had a more positive attitude towards environmental education (Zachariou et al., 2017).

It seems, therefore, important that the Greek Ministry of Education implements more environmental education programs in the Greek educational system, which will raise awareness in students and make them more active in environmental protection (Daskolia, 2005). 
An interesting outcome of the survey was that the teachers' and the students' sensitization towards environmental education were highly linked. The teachers' mobilization also serves as a motive for the students to further expand their knowledge and to be exposed to innovative instructional methods. The students' awareness, however, may act as a multiplier for their families' and friends' awareness towards the environment. Some important factors that emerged were the educational level of their mothers in relation to the level of the students' satisfaction, and the place of residence and the level of education of students in relation to the "Need of Implementation" and the level of "Knowledge and Application of Environmental Education".

Certainly, further research is required in order to reach conclusions on all three pillars of the educational process (students-parents-teachers). It would also be interesting to explore the interaction among these three groups, and how these groups respond to certain actions regarding environmental education as well as the implications of the emphasis of education to the concept of sustainable development (ESD) (Kopnina, 2014). On a national scale, such a research undertaken by the Greek Ministry of Education would reach valuable conclusions, with the aim to raise students' awareness towards environmental quality and contribute to more responsible environmental attitudes and behaviours.

\section{REFERENCES}

Ajzen, I., \& Fishbein, M. (1980). Understanding Attitudes and Predicting Social Behavior. Englewood Cliffs, N.J.: PrenticeHall.

Aydin, F., \& Cepni, O. (2010). 'University students' attitudes towards environmental problems: A case study from Turkey. International Journal of the Physical Sciences, 5(17), 2715-2720.

Aydin, F., Coşkun, M., Kaya, H., \& Erdonmez, I. (2011). Gifted students' attitudes towards environment: A case study from Turkey. African Journal of Agricultural Research, 6(7), 1876-1883.

Bartholomew, D. J., Steele, F., Galbraith, J., \& Moustaki, I. (2008). Analysis of Multivariate Social Science Data (2 ed.). New York: Chapman and Hall/Crc. https://doi.org/ 10.1201/b15114

Beder, S. (2006). Environmental Principles and Policies: An Interdisciplinary Introduction. Sydney, Australia: UNSW Press.

Bonnett, M. (2007). Environmental education and the issue of nature. Journal of Curriculum Studies, 39(6), 707-721. https://doi.org/10.1080/00220270701447149

Brody, S. D., Highfield, W., \& Alston, L. (2004). Does location matter?: Measuring environmental perceptions creeks in two San Antonio watersheds. Environment and Behavior 36(2), 229-250. https://doi.org/10.1177/0013916503256 900
Broom, C. (2017). Exploring the Relations between Childhood Experiences in Nature and Young Adults' Environmental Attitudes and Behaviours. Australian Journal of Environmental Education, 33(1), 34-47. https://doi.org/ 10.1017/aee.2017.1

Buttell, F. H. (1987). New directions in environmental sociology. Annual Review of Sociology, 13, 465-488. https://doi.org/10.1146/annurev.so.13.080187.002341

Chawla, L., \& Cushing, D. F. (2007). Education for strategic environmental behavior. Environmental Education Research, 13(4), 437-452. https://doi.org/10.1080/ 13504620701581539

Cochran, W. G. (1977). Sampling techniques (3rd ed.). NJ: Wiley.

Corraliza, J. A., \& Berenguer, J. (2000). Environmental values, beliefs and actions: A situational approach. Environment and Behavior, 32, 832-848. https://doi.org/10.1177/ 00139160021972829

Daskolia, M. (2005). Theory and practice in environmental education. The personal theories of teachers. Athens: Routledge.

Daskolia, M., Dimos, A., \& Kampylis, P. (2012). Secondary teachers' conceptions of creative thinking within the context of Environmental Education. International Journal of Environmental and Science Education, 7(2), 269-290.

Dunlap, R. E., \& van Liere, K. D. (1978). The "new environmental paradigm": A proposed measuring instrument and preliminary results. Journal of Environmental Education, 9, 10-19. https://doi.org/10.1080/ 00958964.1978.10801875

Dunlap, R. E., van Liere, K. D., Mertig, A. G., \& Jones, R. E. (2000). Measuring endorsement of the new ecological paradigm: A revised NEP scale. Journal of Social Issues, 56, 425-442. https://doi.org/10.1111/0022-4537.00176

Evans, W. G., Brauchle, G., Haq, A., Stecker, R., Wong, K., \& Shapiro E. (2007) Young Children's Environmental Attitudes and Behaviors. Environment and Behavior, 39, 635-658. https://doi.org/10.1177/0013916506294252

Field, A. (2013). Discovering Statistics Using IBM SPSS Statistics (4th Ed.).

Filippou, G., \& Christou, K. (2001). Educational texts, Emotional factors and teaching mathematics. Atrapos (in greek).

Gardner, G., \& Stern, P. C. (2002). Environmental problems and human behavior (2nd ed.). Boston: Allyn and Bacon.

Gifford, R. (2002). Environmental psychology. Victoria, Canada: Optimal Books. https://doi.org/10.1006/jevp.2002.0254

Guagnano, G. A., Stern, P. C., \& Dietz, T. (1995). Influences on attitude behavior relationships: A natural experiment with curbside recycling. Environment and Behavior, 27, 699-718. https://doi.org/10.1177/0013916595275005

Hart, P. (2003). Teachers' Thinking in Environmental Education. (Rethinking Childhood, V. 29).

Hines, J. M., Hungerford, H., \& Tomera, A. (1987). Analysis and synthesis of research on responsible environmental behavior: A meta analysis. Journal of Environmental Education, 18, 1-8. https://doi.org/10.1080/00958964.1987. 9943482 
Huckle, J. (1999). Locating Environmental Education between modern capitalism and postmodern socialism: a reply to Lucie Sauve. Canadian Journal of Environmental Education.

Hungerford, H. R., Volk, T. L., Knapp, D. H., \& Bluhm, M. (1990). Global Change Environmental Education Module. UNESCO-UNAPT International Environmental Education Program. IEEP.

Hwang, S. (2009). Teachers' environmental education as creating cracks and ruptures in school education: a narrative inquiry and an analysis of teacher rhetoric. Environmental Education Research, 15(6), 697-714. https://doi.org/10.1080/13504620903380771

Kaiser, F. G. (1998). A general measure of environmental behavior. Journal of Applied Social Psychology, 28, 395-422. https://doi.org/10.1111/j.1559-1816.1998.tb01712.x

Kaiser, F. G. (2004). Conservation behavior. In C. Spielberger (Ed.), Encyclopedia of applied psychology (Vol. 1, pp. 473477). New York: Academic Press. https://doi.org/10.1016/ B0-12-657410-3/00701-7

Kaiser, F. G., \& Gutscher, H. (2003). The proposition of a general version of the theory of planned behavior: Predicting ecological behavior. Journal of Applied Social Psychology, 33, 586-603. https://doi.org/10.1111/j.15591816.2003.tb01914.x

Kish, L. (1965). Survey Sampling. New York: Wiley.

Kopnina, H. (2014). Future Scenarios and Environmental Education. The Journal of Environmental Education, 45(4), 217-231. https://doi.org/10.1080/00958964.2014.941783

Kotlyakov, V. M., \& Komarova, A. I. (2007). Elsevier's Dictionary of Geography. Amsterdam, The Netherlands: Elsevier.

Kwan, T., \& Miles, J. (1998). In the Words of Children and Young People: The Opinions and Concerns about their Environments of Some Brisbane School Students. Australian Journal of Environmental Education, 14, 11-18. https://doi.org/10.1017/S0814062600003906

Kynigos, C., Daskolia, M., \& Smyrnaiou, Z. (2013).Empowering teachers in challenging times for science and environmental education: Uses for scenarios and microworlds as boundary objects. Contemporary Issues in Education, 3(1), 41-65.

Leeming, F. C., \& Dwyer, W. (1995). Children's environmental attitude and knowledge scale: Construction and evaluation. Journal of Environmental Education, 26, 22-31. https://doi.org/10.1080/00958964.1995.9941442

Maloney, M. P., Ward, M., \& Braucht, G. (1975). A revised scale for the measurement of ecological attitudes and knowledge. American Psychologist, 30, 787-790. https://doi.org/10.1037/h0084394

Miller, J. D. (1975). The development of pre-adult attitudes toward environmental conservation and pollution. School Science and Mathematics, 27, 729-737. https://doi.org/ 10.1037/h0084394

Ministry of Environment, Energy and Climate Change (2011). Retrieved from http://www.ypeka.gr/Default.aspx?tabid= 224\&locale=en-US \&language $=\mathrm{el}-\mathrm{GR}$
Musser, L. M., \& Diamond, K. E. (1999). The children's attitudes toward the environment scale. Journal of Environmental Education, 30, 23-30. https://doi.org/ 10.1080/00958969909601867

Musser, L. M., \& Malkus, A. (1994). The children's attitudes toward the environment scale. Journal of Environmental Education, 25, 22-26. https://doi.org/10.1080/00958964. 1994.9941954

Orr, D. W. (2004). Earth in Mind: On Education, Environment, and the Human Prospect.

Palmer, J. (1998). Environmental Education in the 21st Century: Theory, Practice, Progress and Promise.

Papadopoulos, D. (2005). Development, implementation and evaluation of programs of environmental education for operation of solidly waste. National and Kapodistrian University of Athens (in greek).

Ruffell, M., Mason, J., \& Allen, B. (1998). Studying attitude to mathematics. Educational Studies in Mathematics, 1, 1-18. https://doi.org/10.1023/A:1003019020131

Sachlas, A., \& Bersimis, S. (2016). Applied Statistics using IBM SPSS Statistics 23: Focusing on Health Sciences (in greek).

Sarkar, M. (2011). Secondary students' environmental attitudes: the case of environmental education in Bangladesh. International journal of academic research in business and social sciences, 1(3 Special), 96-109.

Schiza, K. (2005). Environmental Education: an education for the reality and the area we share. Environmental policy, 5, 11-17 (in greek).

Schultz, P. W. (2001). Assessing the structure of environmental concern: Concern for self, other people, and the biosphere. Journal of Environmental Psychology, 21, 327339. https://doi.org/10.1006/jevp.2001.0227

Shephard K., Samuel M., Smith N., \& Deaker L., (2009). Benchmarking the environmental values and attitudes of students in New Zealand's post-compulsory education. Environmental Education Research, 15(5), 571-587. https://doi.org/10.1080/13504620903050523

Smith, A. D. (2001). Perception and Belief. Philosophy and Phenomenological Research, LXII(2). https://doi.org/ 10.1111/j.1933-1592.2001.tb00057.x

Spiropoulou, D. (2002). Environmental Education about weather and protect of atmosphere. Review of Scientific and Educational Issues, 6, 160-171 (in greek).

Staats, H. (2003). Understanding proenvironmental attitudes and behavior: An analysis and review of research based on the theory of planned behavior. In M. Bonnes, T. Lee, and M. Bonaiuto (Eds.), Psychological theories for environmental issues (pp. 171-201). Aldershot, UK: Ashgate.

Stern, P. C. (2000). Toward a coherent theory of environmentally significant behavior. Journal of Social Issues, 36, 407-424. https://doi.org/10.1111/00224537.00175

Stevenson, R., Brody, M., Dillon, J., \& Wals A. (2013). International Handbook of Research on Environmental Education. American Educational Research Association. https://doi.org/10.4324/9780203813331 
Tilbury, D. (1995). Environmental Education for Sustainability: defining the new focus of environmental education in the 1990s. Environmental Education Research, 1(2), 195-212. https://doi.org/10.1080/1350462950010206

Trikaliti, A. (1995). Exploration of cognitive, sociological and psychological factors in Environmental Education. National and Kapodistrian University of Athens (in greek).

Tsantas, N., Moysiadis, Ch., Bayiatis, D., \& Chadjipantelis, T. (1999). Data Analysis using statistical packages (in Greek). Zitis Publications, Thessaloniki.

Vining, J., \& Ebreo, A. (2002). Emerging theoretical and methodological perspectives on conservation behavior. In R. B. Bechtel and A. Churchman (Eds.), Handbook of environmental psychology (2nd ed., pp. 541-558). New York: John Wiley.
Waktola, D. K. (2009). Challenges and opportunities in mainstreaming environmental education into the curricula of teachers' colleges in Ethiopia. Environmental Education Research, 15(5), 589-605. https://doi.org/10.1080/ 13504620903151024

Williams, S. M., \& McCrorie, R. (1990). The analysis of ecological attitudes in town and country. Journal of Environmental Management, 31, 157-162. https://doi.org/10.1016/S0301-4797(05)80005-2

Winter, D., \& Koger, S. D. (2004). Psychology of everyday problems (2nd ed.). Mahwah, NJ: Lawrence Erlbaum.

Zachariou, F. (2008). Attitudes of the quality of environment of students and teachers in Viotia prefecture. Hellenic Open University (in greek).

Zachariou, F., Tsami, E, Chalkias, C., \& Bersimis, S. (2017). Teachers' Attitudes towards the Environment and Environmental Education: An Empirical Study, International Journal of Environmental and Science Education, 12(7), 1567-1593.

\section{APPENDIX}

Table 7. Main descriptive Statistics of the Sample

\begin{tabular}{|c|c|c|c|}
\hline Characteristic & Values & Frequencies & Relative Frequencies \\
\hline \multirow{2}{*}{ Gender } & Males & 500 & $47.3 \%$ \\
\hline & Females & 559 & $52.7 \%$ \\
\hline \multirow{4}{*}{ Educational Level } & High School & 481 & $45.4 \%$ \\
\hline & Senior High School (General) & 375 & $35.4 \%$ \\
\hline & Senior High School (Vocational) & 160 & $15.1 \%$ \\
\hline & Vocational School & 43 & $4.1 \%$ \\
\hline \multirow{4}{*}{ Class Level } & $\mathrm{A}$ & 364 & $34.4 \%$ \\
\hline & $\mathrm{B}$ & 327 & $30.9 \%$ \\
\hline & $\mathrm{C}$ & 363 & $34.3 \%$ \\
\hline & D (Evening School) & 5 & $0.4 \%$ \\
\hline \multirow{3}{*}{ Place of Residence } & Urban Centres (Thebes, Livadia) & 449 & $42.4 \%$ \\
\hline & Semi-Urban Centres & 324 & $30.6 \%$ \\
\hline & Rural Areas & 286 & $27 \%$ \\
\hline \multirow{3}{*}{ Parents' Education } & Father - University Graduate & 239 & $22.6 \%$ \\
\hline & Father - Senior High School Graduate & 426 & $40.2 \%$ \\
\hline & Mother - Senior High School Graduate & 501 & $47.3 \%$ \\
\hline \multirow{9}{*}{ Parents' Employment } & Farmer & 127 & $12 \%$ \\
\hline & Public Servants & 116 & $11 \%$ \\
\hline & Employees in private companies & 159 & $15 \%$ \\
\hline & Freelancers & 138 & $13 \%$ \\
\hline & Professional Drivers & 74 & $7 \%$ \\
\hline & Merchants & 64 & $6 \%$ \\
\hline & Contraction Workers & 85 & $8 \%$ \\
\hline & Mother - Homemakers & 498 & $47 \%$ \\
\hline & Mother - Private sector employees & 169 & $16 \%$ \\
\hline
\end{tabular}

